\title{
Optimization of Medium Composition for Biomass Production of Lactobacillus plantarum 200655 Using Response Surface Methodology
}

\author{
Ga-Hyun Choi, Na-Kyoung Lee, and Hyun-Dong Paik* \\ Department of Food Science and Biotechnology of Animal Resources, Konkuk University, Seoul 05029, Republic of Korea
}

This study aimed to optimize medium composition and culture conditions for enhancing the biomass of Lactobacillus plantarum 200655 using statistical methods. The one-factor-at-a-time (OFAT) method was used to screen the six carbon sources (glucose, sucrose, maltose, fructose, lactose, and galactose) and six nitrogen sources (peptone, tryptone, soytone, yeast extract, beef extract, and malt extract). Based on the OFAT results, six factors were selected for the PlackettBurman design (PBD) to evaluate whether the variables had significant effects on the biomass. Maltose, yeast extract, and soytone were assessed as critical factors and therefore applied to response surface methodology (RSM). The optimal medium composition by RSM was composed of $31.29 \mathrm{~g} / \mathrm{l}$ maltose, $30.27 \mathrm{~g} / \mathrm{l}$ yeast extract, $39.43 \mathrm{~g} / \mathrm{l}$ soytone, $5 \mathrm{~g} / \mathrm{l}$ sodium acetate, $2 \mathrm{~g} / \mathrm{l} \mathrm{K} \mathrm{HPO}_{4}, 1 \mathrm{~g} / \mathrm{l}$ Tween $80,0.1 \mathrm{~g} / \mathrm{l} \mathrm{MgSO}{ }_{4} \cdot 7 \mathrm{H}_{2} \mathrm{O}$, and $0.05 \mathrm{~g} / \mathrm{MnSO}_{4} \cdot \mathrm{H}_{2} \mathrm{O}$, and the maximum biomass was predicted to be $3.951 \mathrm{~g} / \mathrm{l}$. Under the optimized medium, the biomass of $L$. plantarum 200655 was $3.845 \mathrm{~g} / \mathrm{l}$, which was similar to the predicted value and 1.58-fold higher than that of the unoptimized medium ( 2.429 $\mathrm{g} / \mathrm{l})$. Furthermore, the biomass increased to $4.505 \mathrm{~g} / \mathrm{l}$ under optimized cultivation conditions. For lab-scale bioreactor validation, batch fermentation was conducted with a 5-L bioreactor containing 3.5 L of optimized medium. As a result, the highest yield of biomass ( $5.866 \mathrm{~g} / \mathrm{l})$ was obtained after 18 h of incubation at $30^{\circ} \mathrm{C}, \mathrm{pH} 6.5$, and $200 \mathrm{rpm}$. In conclusion, mass production by L. plantarum 200655 could be enhanced to obtain higher yields than that in MRS medium

Keywords: Probiotics, Lactobacillus plantarum, medium optimization, plackett-burman design, response surface methodology

Received: March 10, 2021 Accepted: March 25, 2021

First published online: March 26, 202

*Corresponding author Phone: +82-2-2049-6011 Fax: +82-2-455-3082 E-mail:hdpaik@konkuk.ac.kr

pISSN 1017-7825 elSSN 1738-8872

Copyright(C) 2021 by The Korean Society for Microbiology and Biotechnology

\section{Introduction}

The consumption of probiotics as functional foods or supplements has increased with the growing interest of consumers. Due to various health benefits such as balancing microbiota composition, improving immunity, protecting against intestinal pathogens, and controlling bowel diseases, the popularity of probiotics has grown remarkably in recent years [1]. As the importance of probiotics is consistently emphasized, research related to large-scale industrial production of probiotics has become necessary to satisfy the increasing demand.

Lactic acid bacteria (LAB), including the genera Bifidobacterium, Lactobacillus, Lactococcus, Enterococcus, and Streptococcus, are normally regarded as probiotics [1]. Probiotic LAB can survive in the human gut and play a vital role not only in the gut microbiome but also in the brain. They offer therapeutic effects against various diseases by producing bioactive molecules such as short-chain fatty acids, $\gamma$-aminobutyric acid, exopolysaccharides, acetylcholine, serotonin, and vitamins [2]. Additionally, probiotics show anti-allergic, antioxidant, immunostimulatory, and cholesterol-lowering effects [3-5].

Among the strains of lactobacilli, which consist of more than 50 species, Lactobacillus plantarum is one of the most widespread, versatile LAB traditionally used in the fermentation of vegetables, meat, and dairy [6]. L. plantarum 200655, which was used in this study, was isolated from Korean kimchi. This strain exerts antioxidant effects and can enhance immunity by stimulating the production of cytokines such as IL-1 $\beta$ and IL- 6 [7]. Moreover, heat-killed L. plantarum 200655 shows neuroprotective effects against oxidative stress induced by $\mathrm{H}_{2} \mathrm{O}_{2}[8]$.

The commercial medium used for Lactobacillus is MRS (de Man, Rogosa, and Sharp), which is comprised of essential nutrients (acetate, magnesium, manganese, and polysorbate) and growth-inhibiting ingredients to prevent undesirable bacterial growth. However, the MRS medium is insufficient for maximizing the growth of some Lactobacillus strains [9]. Lactobacilli are fastidious bacteria that require rich media because their capacity to 
metabolize nutrients, such as sugars, amino acids, peptides, and vitamins, varies depending on the strain $[6,10]$. Therefore, the production of viable cells, biomass, and metabolites of $L$. plantarum is significantly affected by the components of the medium and cultivation conditions. If a new medium for each strain or species could be devised as an alternative to conventional media, it would lead to enhanced biomass production and economical benefits including the reduction of cost, wastewater, and fermentation time [10,11].

To find effective ways to increase the yield of desired products, we optimized the medium using various strategies. One of the classical methods is one-factor-at-a-time (OFAT) in which only one factor is changed while the other factors are fixed constant. Although it is simple and convenient, OFAT involves a large number of experiments with an increasing number of factors. Moreover, the method disregards the interactions between factors $[12,13]$. Thus, statistical methods such as Plackett-Burman design (PBD), factorial design, and response surface methodology (RSM) are preferred owing to their efficiency. Furthermore, RSM includes factorial designs and multiple regression analysis and considers the effects of factors, relationships between variables, and optimal conditions [14].

Although many studies have reported medium optimization of $L$. plantarum to enhance its production of metabolites such as lactic acid [14, 15], bacteriocin [16], and exopolysaccharides [17, 18], few studies have focused on biomass production by $L$. plantarum $[11,19]$. Therefore, we used RSM to optimize the medium and fermentation conditions to enable enhanced biomass production by L. plantarum 200655.

\section{Materials and Methods \\ Bacterial Strain and Medium}

L. plantarum 200655 (KCCM 12204P) isolated from Korean kimchi was used in this study. Stock cultures were stored at $-80^{\circ} \mathrm{C}$ in MRS broth (Difco, USA) with $20 \%(\mathrm{v} / \mathrm{v})$ sterile glycerol. The strain was incubated at $37^{\circ} \mathrm{C}$ for $24 \mathrm{~h}$ in MRS medium and activated at least twice before use.

The basal medium was derived from MRS medium and consisted of $5 \mathrm{~g} / 1$ sodium acetate (Sigma, USA), $2 \mathrm{~g} / \mathrm{l}$ $\mathrm{K}_{2} \mathrm{HPO}_{4}$ (Samchun, Korea), $1 \mathrm{~g} / \mathrm{l}$ Tween 80 (Yakuri Pure Chemicals Co. Ltd., Japan), $0.1 \mathrm{~g} / 1 \mathrm{MgSO}_{4} \cdot 7 \mathrm{H}_{2} \mathrm{O}$ (Shinyo Pure Chemicals Co., Japan), and $0.05 \mathrm{~g} / 1 \mathrm{MnSO}_{4} \cdot \mathrm{H}_{2} \mathrm{O}$ (Samchun). Basal medium was added to all media used in this study. The initial $\mathrm{pH}$ of all media was adjusted to $6.5 \pm 0.05$ with $1 \mathrm{M} \mathrm{NaOH}$ and $1 \mathrm{M} \mathrm{HCl}$ before sterilization. The MRS medium was used as a control (unoptimized medium) for comparison with the optimized medium.

Each fermentation condition for optimized medium was as follows: A colony was inoculated in MRS broth and incubated to an optical density (OD) of $0.5 \pm 0.05$ at $600 \mathrm{~nm}$. One hundred milliliters of the medium were inoculated with $1 \%(\mathrm{v} / \mathrm{v})$ of seed culture in a $250-\mathrm{ml}$ Erlenmeyer flask and incubated at $37^{\circ} \mathrm{C}$ for $24 \mathrm{~h}$ without shaking.

\section{Measurement of Biomass}

Culture broth $(50 \mathrm{ml})$ was collected and separated by centrifugation at $4,000 \times g$ for $15 \mathrm{~min}$ at $4^{\circ} \mathrm{C}$. The supernatant was discarded, and the cell pellets were washed twice with sterile distilled water. Biomass was obtained by drying at $80^{\circ} \mathrm{C}$ until it reached a constant weight in a dry oven.

\section{Determination of Medium Compositions Using OFAT}

To investigate the effects of carbon and nitrogen sources on bacterial cell mass, the OFAT method was used. This method can estimate the effects of each variable, but it does not consider the interactions between variables. Before proceeding with the OFAT method, the API 50 CHL Medium Kit (BioMerieux, France) was used to assess the availability of metabolizing carbohydrates. Glucose, sucrose, maltose, fructose, lactose, and galactose were selected, and six carbon sources were added individually to $100 \mathrm{ml}$ of basal medium containing $10 \mathrm{~g} / \mathrm{l}$ yeast extract at a concentration of $20 \mathrm{~g} / \mathrm{l}$. Likewise, six nitrogen sources (peptone, soytone, tryptone, yeast extract, beef extract, and malt extract) were added to $100 \mathrm{ml}$ of basal medium containing $20 \mathrm{~g} / \mathrm{l}$ glucose at a concentration of $10 \mathrm{~g} / \mathrm{l}$.

\section{Plackett-Burman Design (PBD)}

PBD was used to screen for significant factors affecting the biomass production by L. plantarum 200655. Based on the preliminary screening results, three highly influential variables were selected for each of the carbon and nitrogen sources. Those six variables were maltose, sucrose, lactose, yeast extract, soytone, and tryptone, and the variables represented at high and low levels were coded as +1 and -1 , respectively. The design matrix with 12 runs and the actual values of the variables are shown in Table 2. The response values indicate the biomass of L. plantarum 200655. All experiments were conducted in triplicate. The variables that had positive effects on biomass production at a confidence level higher than $95 \%$ were considered for further experiments.

\section{Central Composite Design and Response Surface Methodology}

The RSM with CCD was conducted to optimize the concentration of medium components and estimate the effects of each variable and the interactions between variables. Maltose, yeast extract, and soytone were used as the independent variables. Variables were set at five different levels $(-\alpha,-1,0,1, \alpha)$, and the range of actual values is presented in Table 4. The experimental design of the CCD was made up of a full factorial design with six center points (Table 5). The media were prepared according to a combination of variables in the experimental runs, and all experiments were conducted under static conditions. The obtained biomass was used to establish the regression model, and the quadratic polynomial equation for the variables was as follows: 


$$
Y=\beta_{0}+\sum \beta_{i} X_{i}+\sum \beta_{i j} X_{i} X_{j}+\sum \beta_{i i} X_{i}^{2}
$$

where $\mathrm{Y}$ is the response value of the dependent variable (biomass of $L$. plantarum 200655); $\beta_{0}, \beta_{\mathrm{i}}$, $\beta_{\mathrm{i}}$, and $\beta_{\mathrm{ii}}$ are intercept, linear, interaction, and squared coefficients of the model, respectively; $\mathrm{X}_{\mathrm{i}}$ and $\mathrm{X}_{\mathrm{i}}$ are the independent variables.

\section{Effects of Culture $\mathrm{pH}$ and Temperature}

The effects of initial $\mathrm{pH}$ and incubation temperature were investigated to determine the optimal cultivation conditions for L. plantarum 200655. The $\mathrm{pH}$ was adjusted from 4.0 to 9.0 with $1 \mathrm{M} \mathrm{NaOH}$ and $1 \mathrm{M} \mathrm{HCl}$ before sterilization, and the incubation temperature was set from 22 to $37^{\circ} \mathrm{C}$. The optimal conditions were assessed by comparing the biomass after $24 \mathrm{~h}$ of incubation.

\section{Scale-Up Fermentation of Optimized Medium}

Scale-up fermentation of $L$. plantarum 200655 under the optimized medium and conditions was performed in a 5 -1 bioreactor with a working volume of 3.5 1 . The medium was inoculated with $1 \%(\mathrm{v} / \mathrm{v})$ of seed culture grown in the MRS medium for $24 \mathrm{~h}$. The temperature was controlled at $30^{\circ} \mathrm{C}$, and the $\mathrm{pH}$ was maintained at 6.5 , with $3 \mathrm{M}$ $\mathrm{NaOH}$ and $3 \mathrm{M} \mathrm{HCl}$. The agitation speed was maintained at $200 \mathrm{rpm}$. The MRS medium was used as a control, and fermentation was performed under the same conditions. Biomass and cell viability were measured for $24 \mathrm{~h}$. Fifty milliliters of culture broth was collected to measure the biomass, and cell viability was measured on MRS agar plates after incubation at $37^{\circ} \mathrm{C}$ for $24 \mathrm{~h}$.

\section{Statistical Analysis}

All experiments were repeated in triplicate. Data are presented as the mean \pm SD. One-way analysis of variance and Duncan's multiple range test were used to determine the degree of significant differences. Values were considered significant at $p<0.05$, and all analyses were performed using SPSS (IBM, USA). PBD and RSM were performed using Minitab 18 software (Minitab 18 Inc., USA).

\section{Results and Discussions}

Effects of Carbon and Nitrogen Sources on Biomass Production by L. plantarum 200655

Various carbon and nitrogen sources were evaluated to identify the factors that have profound effects on biomass production by L. plantarum 200655. The basal medium contained $20 \mathrm{~g} / \mathrm{l}$ of each carbon source and $10 \mathrm{~g} / \mathrm{l}$ of each nitrogen source. The biomass obtained from maltose was $2.253 \mathrm{~g} / \mathrm{l}$, which was the highest value among the six carbon sources, whereas sucrose, lactose, glucose, fructose, and galactose were 1.753, 1.749, 1.703, 1.459, and $1.401 \mathrm{~g} / \mathrm{l}$, respectively. Maltose was the most preferred carbon source by L. plantarum 200655, compared to other carbon sources $(p<0.05)$.

Maltose utilization is related to maltose-related genes such as MALS (encoding maltase gene), MALT (encoding maltose permease gene), and MALR (transcriptional activator gene of the MALS and MALT). These results are similar to those of a study by Yeo et al. [9], where maltose was determined to be a suitable carbon source for Lactobacillus salivarius W13 among eight carbon sources. Maltose medium showed significant cell growth of $5.2 \times 10^{8} \mathrm{CFU} / \mathrm{ml}$, which was 2.47 -fold higher than that in MRS medium. Lim et al. [20] reported that the cell growth by Lactobacillus brevis HYE1 increased proportionally in accordance with maltose concentrations between 0.2 to $4 \%$. Although maltose was an optimal carbon source for L. plantarum 200655, the three highest components (maltose, sucrose, and lactose) were selected for the following steps.

Table 1 also shows the biomass according to the six nitrogen sources. It was obvious that different nitrogen sources in the medium had different effects on biomass production. When malt extract was added to the medium, L. plantarum 200655 showed a tremendously low biomass production $(0.022 \mathrm{~g} / \mathrm{l})$. Although malt extract could help L. plantarum, L. acidophilus, and L. reuteri survive in acidic conditions at pH 2.5 [21], L. plantarum 200655 cannot utilize the malt extract as a nitrogen source for growth. When $2.5 \%$ malt extract was added to the medium, L. brevis HYE1 showed similar levels of cell growth to that in the absence of any nitrogen source [20]. Beef extract

Table 1. Effects of various carbon and nitrogen sources on biomass production of L. plantarum 200655.

\begin{tabular}{|c|c|c|}
\hline \multicolumn{2}{|c|}{ Components } & \multirow{2}{*}{$\begin{array}{c}\text { Biomass }(\mathrm{g} / \mathrm{l}) \\
1.703\end{array}$} \\
\hline Carbon sources & Glucose & \\
\hline \multirow{11}{*}{ Nitrogen sources } & Sucrose & 1.753 \\
\hline & Maltose & 2.253 \\
\hline & Fructose & 1.459 \\
\hline & Lactose & 1.749 \\
\hline & Galactose & 1.401 \\
\hline & Peptone & 1.175 \\
\hline & Soytone & 1.480 \\
\hline & Tryptone & 1.371 \\
\hline & Yeast extract & 1.722 \\
\hline & Beef extract & 0.495 \\
\hline & Malt extract & 0.022 \\
\hline
\end{tabular}


Table 2. Experimental design and response values of Plackett-Burman design.

\begin{tabular}{cccccccc}
\hline \multirow{2}{*}{ Run } & \multicolumn{9}{c}{ Variables $^{\mathrm{a}}$} \\
\cline { 2 - 7 } & $\mathrm{X}_{1}(\mathrm{~g} / \mathrm{l})$ & $\mathrm{X}_{2}(\mathrm{~g} / \mathrm{l})$ & $\mathrm{X}_{3}(\mathrm{~g} / \mathrm{l})$ & $\mathrm{X}_{4}(\mathrm{~g} / \mathrm{l})$ & $\mathrm{X}_{5}(\mathrm{~g} / \mathrm{l})$ & $\mathrm{X}_{6}(\mathrm{~g} / \mathrm{l})$ \\
\hline 1 & $1(30)$ & $-1(10)$ & $1(30)$ & $-1(5)$ & $-1(5)$ & $-1(5)$ & 2.036 \\
2 & $1(30)$ & $1(30)$ & $-1(10)$ & $1(10)$ & $-1(5)$ & $-1(5)$ & 2.407 \\
3 & $-1(10)$ & $1(30)$ & $1(30)$ & $-1(5)$ & $1(10)$ & $-1(5)$ & 2.109 \\
4 & $1(30)$ & $-1(10)$ & $1(30)$ & $1(10)$ & $-1(5)$ & $1(10)$ & 2.407 \\
5 & $1(30)$ & $1(30)$ & $-1(10)$ & $1(10)$ & $1(10)$ & $-1(5)$ & 2.561 \\
6 & $1(30)$ & $1(30)$ & $1(30)$ & $-1(5)$ & $1(10)$ & $1(10)$ & 2.360 \\
7 & $-1(10)$ & $1(30)$ & $1(30)$ & $1(10)$ & $-1(5)$ & $1(10)$ & 2.232 \\
8 & $-1(10)$ & $-1(10)$ & $1(30)$ & $1(10)$ & $1(10)$ & $-1(5)$ & 2.181 \\
9 & $-1(10)$ & $-1(10)$ & $-1(10)$ & $1(10)$ & $1(10)$ & $1(10)$ & 2.432 \\
10 & $1(30)$ & $-1(10)$ & $-1(10)$ & $-1(5)$ & $1(10)$ & $1(10)$ & 2.514 \\
11 & $-1(10)$ & $1(30)$ & $-1(10)$ & $-1(5)$ & $-1(5)$ & $1(10)$ & 2.122 \\
12 & $-1(10)$ & $-1(10)$ & $-1(10)$ & $-1(5)$ & $-1(5)$ & $-1(5)$ & 2.079 \\
\hline
\end{tabular}

Actual values are presented in parentheses.

${ }^{\mathrm{a}} \mathrm{X}_{1}$, maltose; $\mathrm{X}_{2}$, sucrose; $\mathrm{X}_{3}$, lactose; $\mathrm{X}_{4}$, yeast extract; $\mathrm{X}_{5}$, soytone; $\mathrm{X}_{6}$, tryptone.

is also not effective for the growth of $L$. plantarum 200655. Yeast extract resulted in maximum biomass production $(1.722 \mathrm{~g} / \mathrm{l})$, followed by soytone $(1.480 \mathrm{~g} / \mathrm{l})$, and tryptone $(1.371 \mathrm{~g} / \mathrm{l})$. When $50 \%$ yeast extract in the medium was replaced with beef or malt extract, the biomass of Lactobacillus sakei CCUG 42687 was reduced from 3.9 to $3.6 \mathrm{~g} / \mathrm{l}$ and then to $2.7 \mathrm{~g} / 1$ [22]. According to Lee et al. [24], the highest cell density of L. acidophilus A12 was obtained in yeast extract medium, whereas the strain showed little preference for beef and malt extracts. Yeast extract promoted high biomass production and lactic acid metabolism in LAB owing to its higher abundance of nitrogenous bases and vitamin B [15].

\section{Plackett-Burman Design for Screening Variables}

Because PBD is an efficient tool for estimating the main effect of each variable, it was applied to identify the most significant variables before performing RSM. Maltose, sucrose, lactose, yeast extract, soytone, and tryptone were selected as variables for PBD. They were set at two different levels $(-1,1)$, where the actual values were 10 to $30 \mathrm{~g} / \mathrm{l}$ and 5 to $10 \mathrm{~g} / \mathrm{l}$ respectively. The six variables with 12 experimental runs resulted in biomass production ranging from 2.036 to $2.561 \mathrm{~g} / \mathrm{l}$ (Table 2). The experiments were conducted in triplicate in accordance with combinations of variables. The standardized effects of the variables are represented as a single column on the Pareto chart (Fig. 1). The vertical line through the column indicates whether the variables are statistically significant. Where the columns crosses over the line and extends to the right shows that the variables had a large effect on the biomass. Table 3 shows the effects of the variables and analysis of variance. The effects of maltose $\left(\mathrm{X}_{1}\right)$, sucrose $\left(\mathrm{X}_{2}\right)$, lactose $\left(\mathrm{X}_{3}\right)$, yeast extract $\left(\mathrm{X}_{4}\right)$, soytone $\left(\mathrm{X}_{5}\right)$, and tryptone $\left(\mathrm{X}_{6}\right)$ were $0.1884,0.0236,-0.1318,0.1667$, 0.1456 , and 0.1158 , respectively. Only lactose had a negative effect on biomass production among the six variables, suggesting that biomass production was decreased by increasing the concentration of lactose in the medium in the tested concentration of $10 \mathrm{~g} / \mathrm{l}$ to $30 \mathrm{~g} / \mathrm{l}$. In contrast, maltose had the highest effect, followed by the yeast extract and soytone. The analysis of variance showed that all components except sucrose were statistically significant $(p<$ $0.05)$. Even though tryptone had positive effects and low probability value, it was excluded from further optimization process because the other two nitrogen sources had higher effects than tryptone. Thus, maltose,

Table 3. Analysis of variables based on Plackett-Burman design.

\begin{tabular}{ccccc}
\hline Variables & Effect & Coefficient & $T$-value & $P$-value \\
\hline Intercept & & 2.2867 & 149.56 & $<0.0001$ \\
$\mathrm{X}_{1}$ & 0.1884 & 0.0942 & 6.16 & 0.0016 \\
$\mathrm{X}_{2}$ & 0.0236 & 0.0118 & 0.77 & 0.4759 \\
$\mathrm{X}_{3}$ & -0.1318 & -0.0659 & -4.31 & 0.0076 \\
$\mathrm{X}_{4}$ & 0.1667 & 0.0833 & 5.45 & 0.0028 \\
$\mathrm{X}_{5}$ & 0.1456 & 0.0728 & 4.76 & 0.0051 \\
$\mathrm{X}_{6}$ & 0.1158 & 0.0579 & 3.79 & 0.0128 \\
\hline
\end{tabular}

Table 4. Coded and real values of independent variables used in the central composite design.

\begin{tabular}{cccccc}
\hline \multirow{2}{*}{ Independent variables $(\mathrm{g} / \mathrm{l})$} & \multicolumn{5}{c}{ Actual levels of coded values } \\
\cline { 2 - 6 } & $-\alpha$ & -1 & 0 & 1 & $\alpha$ \\
\hline Maltose $\left(\mathrm{X}_{1}\right)$ & 8.18 & 15 & 25 & 35 & 41.8 \\
Yeast extract $\left(\mathrm{X}_{2}\right)$ & 8.18 & 15 & 25 & 35 & 41.8 \\
Soytone $\left(\mathrm{X}_{3}\right)$ & 4.77 & 15 & 30 & 45 & 55.2 \\
\hline
\end{tabular}


Table 5. Central composite design and response values.

\begin{tabular}{|c|c|c|c|c|}
\hline \multirow{2}{*}{ Run } & \multicolumn{3}{|c|}{ Independent variables ${ }^{\mathrm{a}}$} & \multirow{2}{*}{ Biomass (g/l) } \\
\hline & $\mathrm{X}_{1}$ & $\mathrm{X}_{2}$ & $\mathrm{X}_{3}$ & \\
\hline 1 & -1 & -1 & -1 & 2.484 \\
\hline 2 & 1 & -1 & -1 & 3.216 \\
\hline 3 & -1 & 1 & -1 & 2.620 \\
\hline 4 & 1 & 1 & -1 & 3.486 \\
\hline 5 & -1 & -1 & 1 & 2.896 \\
\hline 6 & 1 & -1 & 1 & 3.714 \\
\hline 7 & -1 & 1 & 1 & 3.196 \\
\hline 8 & 1 & 1 & 1 & 3.892 \\
\hline 9 & $-\alpha$ & 0 & 0 & 2.348 \\
\hline 10 & $a$ & 0 & 0 & 3.570 \\
\hline 11 & 0 & $-a$ & 0 & 3.354 \\
\hline 12 & 0 & $a$ & 0 & 3.650 \\
\hline 13 & 0 & 0 & $-a$ & 3.232 \\
\hline 14 & 0 & 0 & $a$ & 3.546 \\
\hline 15 & 0 & 0 & 0 & 3.846 \\
\hline 16 & 0 & 0 & 0 & 3.684 \\
\hline 17 & 0 & 0 & 0 & 3.610 \\
\hline 18 & 0 & 0 & 0 & 3.794 \\
\hline 19 & 0 & 0 & 0 & 3.810 \\
\hline 20 & 0 & 0 & 0 & 3.728 \\
\hline
\end{tabular}

${ }^{a} \mathrm{X}_{1}$, maltose; $\mathrm{X}_{2}$, yeast extract; $\mathrm{X}_{3}$, soytone.

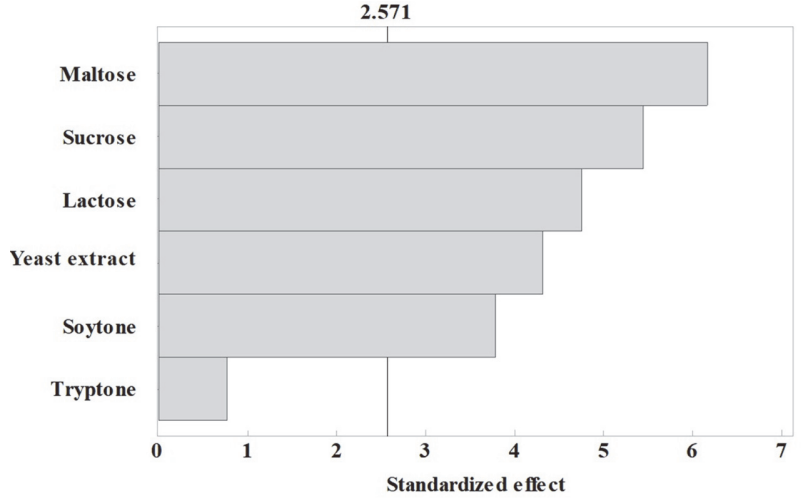

Fig. 1. Pareto chart depicting the standard effects of six factors on the biomass production of L. plantarum 200655.

yeast extract, and soytone were selected as the most important factors for RSM. According to Aasen et al. [22], the best production of biomass and bacteriocin by L. sakei CCUG 42687 was obtained when the medium contained yeast extract and soytone at the same ratio. The model acquired from PBD was fitted well because the determination coefficient $\left(\mathrm{R}^{2}\right)$ was 0.9612 , which indicated that the model could explain $96.12 \%$ of its variability.

\section{Optimization of Medium Components Using Response Surface Methodology}

The CCD model was designed based on RSM to determine the optimal concentrations of maltose $\left(\mathrm{X}_{1}, 8.18 \mathrm{~g} / \mathrm{l}\right.$ to $41.8 \mathrm{~g} / \mathrm{l})$, yeast extract $\left(\mathrm{X}_{2}, 8.18 \mathrm{~g} / \mathrm{l}\right.$ to $\left.41.8 \mathrm{~g} / \mathrm{l}\right)$, and soytone $\left(\mathrm{X}_{3}, 4.77 \mathrm{~g} / \mathrm{l}\right.$ to $\left.55.2 \mathrm{~g} / \mathrm{l}\right)$. The coded units and actual concentrations of the three independent variables are listed in Table 4. Table 5 shows the design matrix consisting of 20 runs and experimental responses, where biomass production varied from 2.348 to $3.892 \mathrm{~g} / \mathrm{l}$. The highest biomass was obtained in run 8 with a concentration of $35 \mathrm{~g} / \mathrm{l}$ maltose, $35 \mathrm{~g} / \mathrm{l}$ yeast extract, and $45 \mathrm{~g} / \mathrm{l}$ soytone. The responses of biomass were analyzed by applying multiple regression analysis, and the second-order polynomial equation, which expressed the relationship between the predicted response and variables, was as follows:

$Y=3.7475+0.3784 X_{1}+0.1012 X_{2}+0.1772 X_{3}-0.2922 X_{1}^{2}-0.1002 X_{2}^{2}-0.1402 X_{3}^{2}+0.0015 X_{1} X_{2}-0.0105 X_{1} X_{3}+$ $0.0090 X_{2} X_{3}$

where $\mathrm{X}_{1}, \mathrm{X}_{2}$, and $\mathrm{X}_{3}$ are maltose, yeast extract, and soytone, respectively.

The analysis of variance presented in Table 6 shows the significance of the quadratic regression model with linear, squared, and interaction terms. As shown in Table 6, a high F-value (33.22) with a very low probability value 
Table 6. Analysis of variance of the response surface quadratic model.

\begin{tabular}{lccccc}
\hline \multicolumn{1}{c}{ Source } & $\mathrm{DF}^{\mathrm{a}}$ & Adj SS $^{\mathrm{b}}$ & Adj MS $^{\mathrm{c}}$ & F-value & $P$-value \\
\hline Model & 9 & 3.99061 & 0.44340 & 33.22 & $<0.0001$ \\
$\mathrm{X}_{1}$ & 1 & 1.95502 & 1.95502 & 146.46 & $<0.0001$ \\
$\mathrm{X}_{2}$ & 1 & 0.13981 & 0.13981 & 10.47 & 0.0089 \\
$\mathrm{X}_{3}$ & 1 & 0.42885 & 0.42885 & 32.13 & 0.0002 \\
$\mathrm{X}_{1} \mathrm{X}_{2}$ & 1 & 0.00002 & 0.00002 & 0.00 & 0.9714 \\
$\mathrm{X}_{1} \mathrm{X}_{3}$ & 1 & 0.00088 & 0.00088 & 0.07 & 0.8024 \\
$\mathrm{X}_{2} \mathrm{X}_{3}$ & 1 & 0.00065 & 0.00065 & 0.05 & 0.8301 \\
$\mathrm{X}_{1}{ }^{2}$ & 1 & 1.23057 & 1.23057 & 92.18 & $<0.0001$ \\
$\mathrm{X}_{2}$ & 1 & 0.14479 & 0.14479 & 10.85 & 0.0081 \\
$\mathrm{X}_{3}{ }^{2}$ & 1 & 0.28321 & 0.28321 & 21.22 & $<0.0010$ \\
Residual & 10 & 0.13349 & 0.01335 & & 2.42 \\
Lack of fit & 5 & 0.09443 & 0.01889 & & 0.1774 \\
Pure error & 5 & 0.03906 & 0.00781 & & \\
Total & 19 & 4.12410 & &
\end{tabular}

$\mathrm{R}^{2}=0.9676$; adjusted $\mathrm{R}^{2}=0.9385 ; \mathrm{R}=0.9837$.

${ }^{\mathrm{a}}$ Degree of freedom.

${ }^{\mathrm{b}}$ Sum of squares.

${ }^{c}$ Mean square.

$((p>F)<0.0001)$ was obtained. The $F$-value is the ratio of the mean square regression to the mean square residual. The critical value of $\mathrm{F}_{(8,10,0.05)}$ tabulated on the $F$ distribution table was 3.07 . The calculated $F$-value greatly exceeded the critical value of $F$, meaning that the null hypothesis could be rejected and that the model was highly significant. The coefficient of determination $\left(R^{2}\right)$ that explains the fit of the model was 0.9676 , implying that $96.76 \%$ of the total variation in response could be elucidated, and only $3.24 \%$ of the variability was not explained by the model. Usually, the $\mathrm{R}^{2}$ value exists between 0 and 1 , and at values closer to 1 , the model could predict the response better. The model with $\mathrm{R}^{2}>0.75$ is regarded as acceptable [24]. Moreover, the adjusted coefficient of determination $\left(R^{2}=0.9385\right)$ and multiple correlation coefficient $(R=0.9837)$ also showed high values, which advocated the close correspondence between the empirical and predicted values. Additionally, the accuracy of the model was also demonstrated by a statistically insignificant lack of fit $(p>0.05)$. The lack of fit indicates that the model failed to express data in the experimental domain at points not involved in the regression [20]. The linear and quadratic effects of maltose $\left(\mathrm{X}_{1}\right)$, yeast extract $\left(\mathrm{X}_{2}\right)$, and soytone $\left(\mathrm{X}_{3}\right)$ significantly affected the biomass of L. plantarum $200655(p<0.05)$. Maltose was the most significant factor $(p<0.0001)$, followed by soytone $(p=$ $0.0002)$ and yeast extract $(p=0.0089)$. Maltose, yeast extract, and soytone can function as limiting nutrients because the quadratic effects of the three variables are highly significant $(p<0.05)$, meaning that a slight modification of their concentrations can affect the biomass [25].

Three-dimensional response surface and contour plots were drawn to express the interactions between the two variables and derive the optimal concentration for maximal biomass production (Fig. 2). Graphical representations having a convex-shaped response surface were depicted based on the model equation. Each graph showed the infinite combinations of two independent variables, with the other one at a constant level. In the optimization of the medium for maximal actinorhodin production by Streptomyces coelicolor A3(2) using RSM, no interactions were found between variables $\left(\mathrm{X}_{1} \mathrm{X}_{2}, \mathrm{X}_{1} \mathrm{X}_{3}\right.$, and $\left.\mathrm{X}_{2} \mathrm{X}_{3}\right)$ because contour plots were relatively round in nature [25]. The insignificance of the interaction terms was also supported by a high probability value $(p>0.05)$. As shown in Figs. 2A and 2B, biomass increased at a maltose concentration between $8.18 \mathrm{~g} / \mathrm{l}$ and $31.29 \mathrm{~g} / \mathrm{l}$, and it declined at concentrations beyond $31.29 \mathrm{~g} / \mathrm{l}$. The concentration of yeast extract and soytone were also analyzed, while that of maltose was maintained at the central point. When the concentration of yeast extract reached $30.27 \mathrm{~g} / \mathrm{l}$, a peak in biomass production was observed. In the case of soytone, a similar profile was observed; the biomass increased at soytone concentrations up to $39.43 \mathrm{~g} / \mathrm{l}$. It seems that high concentrations of the independent variables suppressed the increase in biomass production. When the concentrations of maltose, yeast extract, and soytone were $31.29 \mathrm{~g} / \mathrm{l}, 30.27 \mathrm{~g} / \mathrm{l}$, and $39.43 \mathrm{~g} / \mathrm{l}$, respectively, the regression model predicted a maximum biomass concentration of $3.951 \mathrm{~g} / \mathrm{l}$, with a $95 \%$ confidence interval ranging between 3.835 and $4.067 \mathrm{~g} / \mathrm{l}$.

The predicted model was validated under the optimized conditions by performing independent experiments in triplicate, and the biomass was found to be $3.845 \mathrm{~g} / \mathrm{l}$. The model showed good agreement with the predicted value, and the experimental value was within the $95 \%$ confidence interval range. The biomass in the optimized medium was 1.58 -fold higher compared to that in the unoptimized medium $(2.429 \mathrm{~g} / \mathrm{l})$. Manzoor et al. [11] developed a low-cost medium consisting of $15 \mathrm{~g} / \mathrm{l}$ glucose, $60 \mathrm{~g} / \mathrm{l}$ cheese whey, and $15 \mathrm{~g} / \mathrm{l}$ corn steep liquor using the BoxBehnken method. Viable cells and dry cell mass of $L$. plantarum AS-14 were significantly increased $(p<0.05)$ when incubated in the optimized medium. Selvamani et al. [24] used RSM to optimize a medium containing $68.60 \mathrm{~g} / \mathrm{l}$ lactose, $50 \mathrm{~g} / \mathrm{l}$ yeast extract, and $1 \mathrm{~g} / \mathrm{K}_{2} \mathrm{HPO}_{4}$, which resulted in maximum biomass production $(3.96 \mathrm{~g} / \mathrm{l}) \mathrm{by}$ L. reuteri DSM20016 ${ }^{1}$. Moreover, the optimum concentrations of the medium components for L. plantarum ATCC 8014 were $40 \mathrm{~g} / \mathrm{l}$ molasses, $16.8 \mathrm{~g} / \mathrm{l}$ yeast extract, $2.72 \mathrm{~g} / \mathrm{l} \mathrm{K \textrm {H } _ { 2 }} \mathrm{PO}_{4}$, and $3.98 \mathrm{~g} / \mathrm{l}$ sodium acetate. After $48 \mathrm{~h}$ of fermentation in the optimized medium, a cell mass of $4.40 \mathrm{~g} / \mathrm{l}$ was achieved, which increased up to 4.5 times compared to that in the unoptimized medium [18]. 

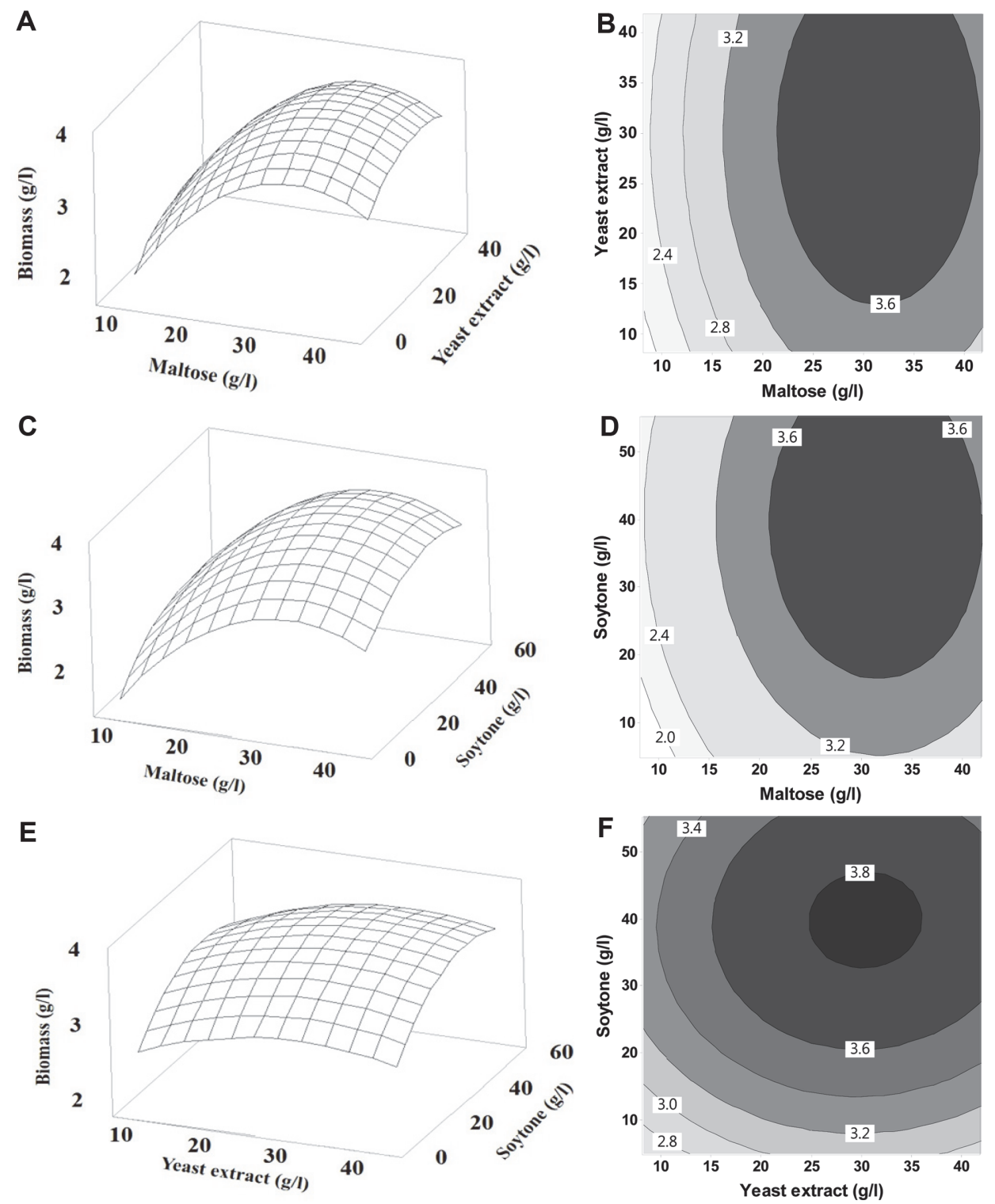

Fig. 2. Response surface plots and contour plots for biomass production of L. plantarum 200655. (A, B) Interaction between maltose $\left(\mathrm{X}_{1}, \mathrm{~g} / \mathrm{l}\right)$ and yeast extract $\left(\mathrm{X}_{2}, \mathrm{~g} / \mathrm{l}\right)$ with soytone $\left(\mathrm{X}_{3}, \mathrm{~g} / \mathrm{l}\right)$ at zero level. $(\mathrm{C}, \mathrm{D})$ Interaction between maltose $\left(\mathrm{X}_{1}, \mathrm{~g} / \mathrm{l}\right)$ and soytone $\left(\mathrm{X}_{3}, \mathrm{~g} / \mathrm{l}\right)$ with yeast extract $\left(\mathrm{X}_{2}, \mathrm{~g} / \mathrm{l}\right)$ at zero level. $(\mathrm{E}, \mathrm{F})$ Interaction between yeast extract $\left(\mathrm{X}_{2}, \mathrm{~g} / \mathrm{l}\right)$ and soytone $\left(\mathrm{X}_{3}, \mathrm{~g} / \mathrm{l}\right)$ with maltose $\left(\mathrm{X}_{1}, \mathrm{~g} / \mathrm{l}\right)$ at zero level.

\section{Effects of $\mathrm{pH}$ of Medium and Fermentation Temperature on Biomass}

The effects of the initial $\mathrm{pH}$ and incubation temperature were investigated in the optimized medium since not only the medium formula but also the physicochemical parameters are important for bacterial growth. It seems that the $\mathrm{pH}$ and temperature affected the biomass production by L. plantarum 200655. As shown in Fig. 3A, the highest biomass $(4.304 \mathrm{~g} / \mathrm{l})$ was obtained at $\mathrm{pH} 7.0$, which decreased sequentially above and below this point. The lowest biomass $(1.124 \mathrm{~g} / \mathrm{l})$ was obtained when the $\mathrm{pH}$ was 4.0 . The biomass decreased dramatically from $\mathrm{pH} 4.0$ to 5.0 , whereas the decline from $\mathrm{pH} 8.0$ to 9.0 was gradual. Low $\mathrm{pH}$ was found to inhibit the growth of L. plantarum 200655. Even though the optimal $\mathrm{pH}$ for most Lactobacillus strains was suggested to be between 5.0 to 6.0, low $\mathrm{pH}$ conditions $(<4.4)$ could inhibit the growth and slow down the growth rate [26]. Moreover, it is possible to grow some strains of LAB under alkaline conditions by regulating the internal $\mathrm{pH}$ by alkalization of the cytoplasm [27]. While acidic and alkaline culture conditions negatively influenced cell growth, neutral conditions were favorable to L. plantarum 200655. Although there were little differences in biomass production within the $\mathrm{pH}$ range of 6.5 to 7.5 , the biomass at $\mathrm{pH} 7.0$ was insignificantly different from that at $\mathrm{pH} 6.5(p=1.000)$ and $\mathrm{pH} 7.5(p=0.999)$. Therefore, $\mathrm{pH} 6.5$ was chosen as the optimal $\mathrm{pH}$ for subsequent experiments.

The effects of temperature were also evaluated using the optimized medium. The maximal biomass $(4.505 \mathrm{~g} / \mathrm{l})$ was attained at $30^{\circ} \mathrm{C}$, which was statistically significant compared to that at other temperatures $(p<0.05)$. The 
A

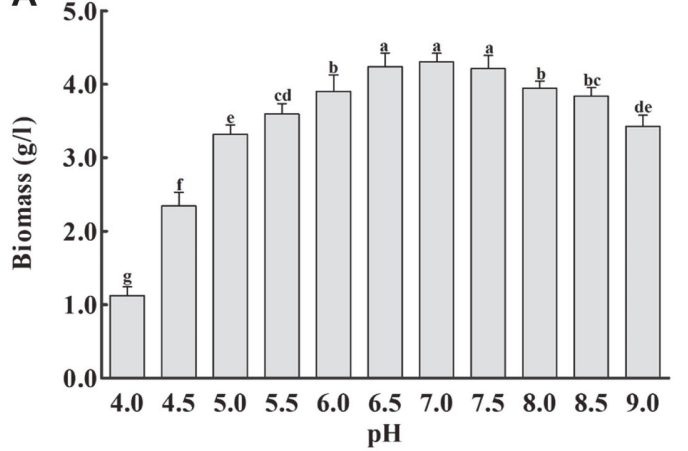

B

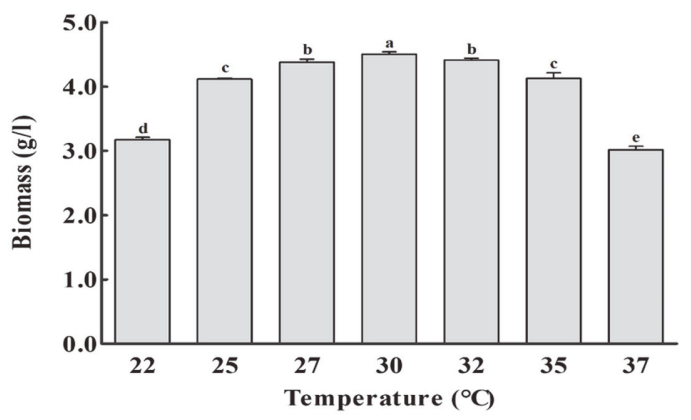

Fig. 3. Effects of initial $\mathrm{pH}(\mathrm{A})$ and incubation temperature (B) on biomass production by L. plantarum 200655. Data are presented as the mean \pm SD of independent experiments in triplicate. Different superscript letters of each figure are significantly different $(p<0.05)$.

biomass decreased when temperatures exceeded $30^{\circ} \mathrm{C}$, and the lowest biomass $(3.019 \mathrm{~g} / \mathrm{l})$ was observed at $37^{\circ} \mathrm{C}$. Optimal biomass production was observed within the $\mathrm{pH}$ range of 6.5 to 7.0 and a temperature of $30^{\circ} \mathrm{C}$. According to Manzoor et al. [11], the best conditions for maximum biomass production by L. plantarum AS- 14 were a temperature of $34-39.6^{\circ} \mathrm{C}$ and a $\mathrm{pH}$ of $6.1-6.4$. Some studies have reported that the maximum biomass production by $\mathrm{LAB}$ was obtained at $\mathrm{pH}$ ranging from 5.2 to 6.3 and an incubation temperature ranging from 22 to $40^{\circ} \mathrm{C}[10,11$, $16,28,29]$

\section{Comparison of Optimized and Unoptimized Media in a Bioreactor}

Fig. 4 presents the time course of $L$. plantarum 200655 regarding biomass production and viable cells cultivated in optimized and unoptimized media (MRS) under the same incubation conditions $\left(30^{\circ} \mathrm{C}, \mathrm{pH}\right.$ 6.5, and an agitation speed of $200 \mathrm{rpm}$ ). The fermentation was performed for $24 \mathrm{~h}$ in a $5-1$ bioreactor containing $3.5 \mathrm{l}$ of each medium. Although a readable increase in biomass was not observed from 0 to $4 \mathrm{~h}$ of incubation in both media, the biomass increased dramatically at $6 \mathrm{~h}$ of fermentation. The highest biomass was obtained after 18 and $15 \mathrm{~h}$ of fermentation in the optimized medium $(5.866 \mathrm{~g} / \mathrm{l})$ and MRS medium $(2.504 \mathrm{~g} / \mathrm{l})$, respectively. A significant difference in biomass production (2.34-fold increase) was observed. The viable cells of $L$. plantarum 200655 are also represented in Fig. 4. Although the maximum number of viable cells $(9.56 \mathrm{log} \mathrm{CFU} / \mathrm{ml}$ ) was observed in the MRS medium after $24 \mathrm{~h}$ of incubation, a higher number of viable cells $(10.03 \mathrm{log} \mathrm{CFU} / \mathrm{ml})$ was observed in the optimized medium at a shorter fermentation time of $18 \mathrm{~h}$. It seems that the optimized medium affected not only the biomass but also the number of viable cells of L. plantarum 200655. Selvamani et al. [24] investigated the growth kinetics of the dry cell weight of $L$. reuteri DSM $20016^{\mathrm{T}}$, and the maximum cell mass was observed after $48 \mathrm{~h}$ of fermentation in an optimized medium by RSM. The biomass of L. reuteri DSM $20016^{\mathrm{T}}$ increased 3 -fold $(3.96 \mathrm{~g} / \mathrm{l})$ in the optimized medium compared to the unoptimized medium $(1.76 \mathrm{~g} / \mathrm{l})$. Fonteles et al. [29] reported that Lactobacillus casei B-442 showed the highest number of viable cells $(8.93 \mathrm{log} \mathrm{CFU} / \mathrm{ml})$ in fermented cantaloupe juice under optimized conditions (fermentation temperature at $31^{\circ} \mathrm{C}$, initial pH 6.1 for $24 \mathrm{~h}$ ).

Therefore, biomass production by $L$. plantarum 200655 could be optimized in a medium comprising $31.29 \mathrm{~g} / \mathrm{l}$ maltose, $30.27 \mathrm{~g} / \mathrm{l}$ yeast extract, $39.43 \mathrm{~g} / \mathrm{l}$ soytone, $5 \mathrm{~g} / \mathrm{l}$ sodium acetate, $2 \mathrm{~g} / \mathrm{l} \mathrm{K}_{2} \mathrm{HPO}_{4}, 1 \mathrm{~g} / \mathrm{l}$ Tween 80, $0.1 \mathrm{~g} / \mathrm{l}$ $\mathrm{MgSO}_{4} \cdot 7 \mathrm{H}_{2} \mathrm{O}$, and $0.05 \mathrm{~g} / 1 \mathrm{MnSO}_{4} \cdot \mathrm{H}_{2} \mathrm{O}$ under the culture conditions of $30^{\circ} \mathrm{C}, \mathrm{pH} 6.5$, and an agitation speed of



Fig. 4. The time course of biomass production and viable cells of $L$. plantarum 200655 in optimized medium $(\odot, \square)$ and unoptimized medium $(O, \square)$. 
$200 \mathrm{rpm}$. In conclusion, this study verified the statistically-optimized medium composition and culture conditions that could be used for enhanced biomass production by L. plantarum 200655.

\section{Acknowledgments}

This work was supported by the Korea Institute of Planning and Evaluation for Technology in Food, Agriculture, and Forestry (IPET) through the Innovational Food Technology Development Program (\#1190093), funded by the Ministry of Agriculture, Food and Rural Affairs (MAFRA).

\section{Conflict of Interest}

The authors have no financial conflicts of interest to declare.

\section{References}

1. Tripathi MK, Giri SK. 2014. Probiotic functional foods: Survival of probiotics during processing and storage. J. Funct. Foods 9: 225241.

2. Nataraj BH, Shivanna SK, Rao P, Nagpal R, Behare PV. 2020. Evolutionary concepts in the functional biotics arena: a mini-review. Food Sci. Biotechnol. 30: 487-496.

3. Lee NK, Kim SY, Han KJ, Eom SJ, Paik HD. 2014. Probiotic potential of Lactobacillus strains with anti-allergic effects from kimchi for yogurt starters. LWT-Food Sci. Technol. 58: 130-134.

4. Son SH, Yang SJ, Jeon HL, Yu HS, Lee NK, Park YS, et al. 2018. Antioxidant and immunostimulatory effect of potential probiotic Lactobacillus paraplantarum SC61 isolated from Korean traditional fermented food, jangajji. Microb. Pathog. 125: 486-492.

5. Asan-Ozusaglam M, Gunyakti A. 2019. Lactobacillus fermentum strains from human breast milk with probiotic properties and cholesterol-lowering effects. Food Sci. Biotechnol. 28: 501-509.

6. de Vries MC, Vaughan EE, Kleerebezem M, de Vos WM. 2006. Lactobacillus plantarum - survival, functional and potential probiotic properties in the human intestinal tract. Int. Dairy J. 16: 1018-1028.

7. Yan SJ, Lee JE, Lim SM, Kim YJ, Lee NK, Paik HD. 2019. Antioxidant and immune-enhancing effects of probiotic Lactobacillus plantarum 200655 isolated from kimchi. Food Sci. Biotechnol. 28: 491-499.

8. Cheon MJ, Lee NK, Paik HD. 2021. Neuroprotective effects of heat-killed Lactobacillus plantarum 200655 isolated from kimchi against oxidative stress. Probiotics Antimicrob. Proteins doi.org/10.1007/s12602-020-09740-w.

9. Yeo S, Shin HS, Lee HW, Hong D, Park H, Holzapfel W, et al. 2018. Determination of optimized growth medium and cryoprotective additives to enhance the growth and survival of Lactobacillus salivarius. J. Microbiol. Biotechnol. 28: 718-731.

10. Brinques GB, Peralba MC, Ayub MAZ. 2010. Optimization of probiotic and lactic acid production by Lactobacillus plantarum in submerged bioreactor systems. J. Ind. Microbiol. 37: 205-212.

11. Manzoor A, Qazi JI, Haq IU, Mukhtar H, Rasool A. 2017. Significantly enhanced biomass production of a novel bio-therapeutic strain Lactobacillus plantarum (AS-14) by developing low-cost media cultivation strategy. J. Biol. Eng. 11: 17.

12. Lee YM, Kim JS, Kim WJ. 2012. Optimization for the maximum bacteriocin production of Lactobacillus brevis DF01 using response surface methodology. Food Sci. Biotechnol. 21: 653-659.

13. Singh V, Haque S, Niwas R, Srivastava A, Pasupuleti M, Tripathi CKM. 2017. Strategies for fermentation medium optimization: an in-depth review. Front. Microbiol. 7:2087.

14. Coelho LF, de Lima CJB, Rodovalho CM, Bernardo MP, Contiero J. 2011. Lactic acid production by new Lactobacillus plantarum LMISM6 grown in molasses: optimization of medium composition. Braz. J. Chem. Eng. 28: 27-36.

15. Liu B, Yang M, Qi B, Chen X, Su Z, Wan Y. 2010. Optimizing L-(+)-lactic acid production by thermophile Lactobacillus plantarum As.1.3 using alternative nitrogen sources with response surface method. Biochem. Eng. J. 52: 212-219.

16. Leal-Sánchez MV, Jiménez-Díaz R, Maldonado-Barragán A, Garrido-Fernández A, Ruiz-Barba JL. 2002. Optimization of bacteriocin production by batch fermentation of Lactobacillus plantarum LPCO10. Appl. Environ. Microbiol. 68: 4465-4471.

17. Desai KM, Akolkar SK, Badhe YP, Tambe SS, Lele SS. 2006. Optimization of fermentation media for exopolysaccharide production from Lactobacillus plantarum using artificial intelligence-based techniques. Process Biochem. 41: 1842-1848.

18. Othman NZ, Mohd Din ARJ, Azam Z, Rosli MA, Sarmidi MR. 2018. Statistical optimization of medium compositions for high cell mass and exopolysaccharide production by Lactobacillus plantarum ATCC 8014. Appl. Food Biotechnol. 5: 87-96.

19. Hwang CF, Chang JH, Houng JY, Tsai CC, Lin CK, Tsen HY. 2012. Optimization of medium composition for improving biomass production of Lactobacillus plantarum Pi06 using the Taguchi array design and the Box-Behnken method. Biotechnol. Bioprocess Eng. 17: 827-834.

20. Lim HS, Cha IT, Roh SW, Shin HH, Seo MJ. 2017. Enhanced production of gamma-aminobutyric acid by optimizing culture conditions of Lactobacillus brevis HYE1 isolated from kimchi, a Korean fermented food. J. Miocrobiol. Biotechnol. 27: 450-459.

21. Charalampopoulos D, Pandiella SS, Webb C. 2003. Evaluation of the effect of malt, wheat and barley extracts on the viability of potentially probiotic lactic acid bacteria under acidic conditions. Int. J. Food Microbiol. 82: 133-141.

22. Aasen IM, Møretrø T, Katla T, Axelsson L, Storrø I. 2000. Influence of complex nutrients, temperature and pH on bacteriocin production by Lactobacillus sakei CCUG 42687. Appl. Microbiol. Biotechnol. 53: 159-166.

23. Lee NK, Park YL, Choe GJ, Chang HI, Paik HD. 2010. Medium optimization for the production of probiotic Lactobacillus acidophilus A12 using response surface methodology. Korean J. Food Sci. An. 30: 359-364.

24. Selvamani S, Dailin DJ, Rostom M, Malek RA, Gupta VK, El-Enshasy HA. 2020. Optimizing medium components to enhance high cell mass production of biotherapeutic strain Lactobacillus reuteri DSM $20016^{\mathrm{T}}$ by statistical method. J. Sci. Ind. Res. 79: 798-803.

25. Elibol M. 2004. Optimization of medium composition for actinorhodin production by Streptomyces coelicolor A3(2) with response surface methodology. Process Biochem. 39: 1057-1062.

26. Hayek SA, Ibrahim SA. 2013. Current limitations and challenges with lactic acid bacteria: a review. Food Nutr. Sci. 4: 73-87.

27. Mbye M, Baig MA, AbuQamar SF, El-Tarabily KA, Obaid RS, Osaili TM, et al. 2020. Updates on understanding of probiotic lactic acid bacteria responses to environmental stresses and highlights on proteomic analyses. Compr. Rev. Food Sci. Food Saf. 19: 11101124 .

28. Coghetto CC, Vasconcelos CB, Brinques GB, Ayub MAZ. 2016. Lactobacillus plantarum BL011 cultivation in industrial isolated soybean protein acid residue. Braz. J. Microbiol. 47: 941-948.

29. Fonteles TV, Costa MGM, de Jesus ALT, Rodrigues S. 2012. Optimization of the fermentation of cantaloupe juice by Lactobacillus casei NRRL B-442. Food Bioprocess Tech. 5: 2819-2826. 